\title{
Article \\ Socioeconomic Status, Health and Lifestyle Settings as Psychosocial Risk Factors for Road Crashes in Young People: Assessing the Colombian Case
}

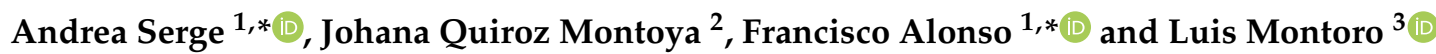 \\ 1 DATS (Development and Advising in Traffic Safety) Research Group, INTRAS (Research Institute on Traffic \\ and Road Safety), University of Valencia, 46022 Valencia, Spain \\ 2 Dipartimento Scienze Statistiche, Faculty: Ingegneria Dell'informazione, Informatica e Statistica, \\ Sapienza Università di Roma, 00185 Rome, Italy; jkquirozm@unal.edu.co \\ 3 FACTHUM.Lab (Human Factor and Road Safety) Research Group, INTRAS (Research Institute on Traffic and \\ Road Safety), University of Valencia, 46022 Valencia, Spain; luis.montoro@uv.es \\ * Correspondence: andrea.serge@uv.es (A.S.); datspublications@gmail.com (F.A.); \\ Tel.: +34-61120-2027 (A.S. \& F.A.)
}

check for updates

Citation: Serge, A.; Quiroz Montoya, J.; Alonso, F.; Montoro, L. Socioeconomic Status, Health and Lifestyle Settings as Psychosocial Risk Factors for Road Crashes in Young People: Assessing the Colombian Case. Int. J. Environ. Res. Public Health 2021, 18, 886. https://doi.org/ 10.3390/ijerph18030886

Received: 20 November 2020

Accepted: 18 January 2021

Published: 20 January 2021

Publisher's Note: MDPI stays neutral with regard to jurisdictional claims in published maps and institutional affiliations.

Copyright: (C) 2021 by the authors Licensee MDPI, Basel, Switzerland. This article is an open access article distributed under the terms and conditions of the Creative Commons Attribution (CC BY) license (https:// creativecommons.org/licenses/by/ $4.0 /)$.

\begin{abstract}
The social determinants of health influence both psychosocial risks and protective factors, especially in high-demanding contexts, such as the mobility of drivers and non-drivers. Recent evidence suggests that exploring socioeconomic status (SES), health and lifestyle-related factors might contribute to a better understanding of road traffic crashes (RTCs). Thus, the aim of this study was to construct indices for the assessment of crash rates and mobility patterns among young Colombians who live in the central region of the country. The specific objectives were developing SES, health and lifestyle indices, and assessing the self-reported RTCs and mobility features depending on these indices. A sample of 561 subjects participated in this cross-sectional study. Through a reduction approach of Principal Component Analysis (PCA), three indices were constructed. Mean and frequency differences were contrasted for the self-reported mobility, crash rates, age, and gender. As a result, SES, health and lifestyle indices explained between 56.3-67.9\% of the total variance. Drivers and pedestrians who suffered crashes had higher SES. A healthier lifestyle is associated with cycling, but also with suffering more bike crashes; drivers and those reporting traffic crashes have shown greater psychosocial and lifestyle-related risk factors. Regarding gender differences, men are more likely to engage in road activities, as well as to suffer more RTCs. On the other hand, women present lower healthy lifestyle-related indices and a less active implication in mobility. Protective factors such as a high SES and a healthier lifestyle are associated with RTCs suffered by young Colombian road users. Given the differences found in this regard, a gender perspective for understanding RTCs and mobility is highly suggestible, considering that socio-economic gaps seem to differentially affect mobility and crash-related patterns.
\end{abstract}

Keywords: epidemiology; socioeconomic status; traffic safety; public health

\section{Introduction}

Much research has been conducted in the field of traffic safety, since the consequences of Road Traffic Crashes (RTCs) and Road Traffic Injuries (RTIs) have been recognized as a major concern for public health $[1,2]$. The numbers show that, worldwide, around 1.35 millions of people die and 50 million are injured as a consequence of road traffic crash-related events [3]. Unfortunately, despite the efforts made by different researchers, governments and institutions, these occurrences are still present in our life.

An important case study is the one corresponding to developing countries. These countries are especially impacted, since, in addition to being economically affected by low economic growth, they also suffer a huge number of crashes. The worrisome part of this 
phenomenon is that several studies point out how RTCs seem to be following a tendency to increase [4,5], affecting specific population groups such as younger and vulnerable road users. The presence of RTCs is detrimental to both the economic wellbeing and the macroeconomic performance of countries [6]. RTCs and RTIs keep a tight relation with the economy and health, not only in what concerns the consequences and burdens associated with their occurrence and prevention [6,7], but also in the explanation of their causes through mobility, as well as in what concerns the psychosocial risk and/or protection factors, such as health determinants and lifestyle.

RTCs as events are predictable, and they can be approached from a perspective that works directly with road actors, or with what is known as the human factor $[8,9]$. The importance of studying them is rooted in that this factor seems to be determinant in RTCs, with at least $67 \%$ of crashes resulting from human errors [10], a proportion that varies depending on the studied population. Traditionally, the study of the human factor in road safety has focused on drivers, since they are the ones with access to vehicles, which may be the element that is most related to traffic. Numerous studies have demonstrated the important role of drivers in the occurrence of RTCs [11,12]; however, nowadays experts have centered their attention on other groups of road actors, especially those that are considered vulnerable, such as pedestrians, cyclists and children. This has led to research on human factors going beyond the study of human errors associated with the driving task [13].

Additionally, this element highlights the need of studying crash rates from a psychological and social perspective, which has already demonstrated how the interrelation of society-economy-health can lead to specific groups being more vulnerable to suffering RTCs, or even influence the perception that people have of these events [14].

Therefore, the study and understanding of crash occurrences, aiming at their possible prevention, must take into account other types of elements beyond the crash itself, and from a multi-disciplinary approach [1]. Let us start with the consideration of socioeconomic status (SES): there is a wide research corpus that has demonstrated how the socioeconomic possibilities of people can influence their life, or even determine their opportunities in the world before they are even born [15]. This happens not only on an individual level, but it also influences different dimensions of life within societies [16].

The SES is framed and recognized as a determinant of health, as well as a predictor of different conditions and situations $[17,18]$, both positively and negatively [19]. The SES widely influences the health risk, having an impact on people's healthcare, environment, and psychosocial functioning [20]. The evidence points out that SES can be used as an explicative element of RTCs, and there is research proving that belonging to a lower social class is associated with a higher frequency of suffering deathly traffic crashes [21,22]. At the same time, an average or high SES appears to be more related to an intention or attitude towards risky behaviors [23], and people who engage in risky behaviors have more chances of suffering a crash [24,25].

As a concept, SES is the result of many other variables, such as age, sex, neighborhood and country [26-29]; for its understanding, Socioeconomic Position (SEP) indicators must be taken into account as well, referring to social and economic factors influencing what position an individual will have within a society [29]. Monthly salary and wealth stand out particularly [30,31], together with residence and housing [29,32], education [33-35] and occupation [36,37].

In a similar way, health is a major dimension that must be considered. As it has been said, RTCs represent a health burden related to deaths, and they are also an important cause of living with an injury-related disability [1,38]. In addition to this, it has been found that the driving task, if prolonged, has a negative impact on health, for instance through an increase of stress and fatigue [39]. The acquisition of not-so-healthy habits, such as sleeping less and performing less physical activity, has also been reported [40]. Moreover, mental health can be compromised too, and health status concerns are associated with poor 
driving behavior [41]. For what concerns the physical aspect, some argue that people with high body mass may be at higher risk of suffering a RTC [42,43].

To sum up, SES, health and lifestyle influence, and even determine, the psychological and social risk or protective factors: better SES, health and lifestyle indices are associated with a better psychological health [44], and the poorer the psychological health, the more probabilities of suffering RTCs $[45,46]$. Now, in order to study the relation of these topics with traffic and road safety, all the above should be considered, starting from the following premises: which country are we talking about? What are the characteristics of people at risk, and of those who suffer these crashes? In the case of Colombia, it has been reported that a driver can be four times more likely to die in a crash, compared with a driver in Spain [47], in addition to a ratio of 18.5 RTC deaths every 100,000 inhabitants [3]. Moreover, young Colombians are a risk group, and they are vulnerable to RTCs [48].

Taking into account that the consideration of SES, health and lifestyle allows us to understand why traffic crashes seem to be present and possibly increasing in developing countries, the objective of this work is to construct indices related to these major topics in order to explore their relationship with RTCs and mobility in a sample of young Colombian participants. The null hypothesis that there are no significant differences between groups is going to be tested for each index, expecting that the groups with the most vulnerable SES, unfavorable health and worse lifestyle will present more crashes and will have patterns of more active mobility. As specific objectives, the study aims at: (1) developing SES, health and lifestyle indices for this country, that will take into account sociodemographic variables, SEP indicators and health-related information; (2) assessing self-reported RTCs and mobility features depending on the SES, health and lifestyle indices.

\section{Materials and Methods}

\subsection{Participants}

Colombia is a country with 44.164 million inhabitants [49]. Several studies have pointed out that, taking into account a confidence level of at least $95 \%$ and a $5 \%$ margin of error, a minimum sample size of $n=385$ is required in order to conduct meaningful analyses [50-52]. We will take this number as our sample reference, assuming that a population group adequately represents the population from which such group is extracted [53,54]. According to the Statuary Law, from 1855 and from 2018, as a modification of the Young Citizens Status, in Colombia young people are those with an age ranging from 14 to 28 years old, and youth is considered the stage during which one's intellectual, moral, physical, economic, social and cultural autonomy are being built [55]. It is reported that young people represent at least $21.8 \%$ of the country's total population [56].

Following a cross-sectional design, the sample was collected through convenience sampling, and participants who were older than 17 were included. Since young people were the study's target, the research relied on the cooperation of university lecturers, who emailed their contacts an invitation to participate. Overall, 20 professors were invited, and 15 of them accepted, thus having a 75\% margin of acceptance. A total of 731 interviews were completed, and after a cleaning and refining process through the age filter $>17$ and $<29$, a final sample of $n=561$ was selected, therefore reducing the margin of error to $4.14 \%$. Most of the respondents $(65.95 \%)$ were from Bogotá, the most populated city in the country, and from municipalities from Cundinamarca surrounding the capital $(30.12 \%)$.

\subsection{Procedure and Data Analysis}

Facing the limitations of web-based surveys but highlighting their economic advantages, their efficiency in collecting data, their reduction of interviewer biases [57], and the fact that, through a rigorous design and development, "results from an online survey may be no different than paper based survey results" [58], this study gathered the data using an online survey named "Encuesta de Salud y Seguridad Vial" ("Survey on Road Safety and Health"), whose average completion time was $40 \mathrm{~min}$. This survey collected data on sociodemographic and crash records information, as well as on some specific scales. It 
was reviewed by two experts: a psychologist with traffic safety experience, and a civil engineer with experience in the assessment of human factor in transportation. After their recommendations, the instrument was tested in a pilot study including 50 participants, which allowed for the elimination of ambiguous items.

To achieve the general and specific objectives, Principal Component Analysis (PCA) was used to construct the indices. Chi Square Independency Test and Student's $t$-test for Independent Samples were performed to compare group means, both with a 95\% level confidence, testing the null hypothesis that there are no significant differences between groups. The $p$ values were adjusted through False Discovery Rate (FDR), which is thought to be the best approach, "as it not only reduces false positives, but also minimizes false negatives" [59]. Finally, a violin plot to show the full distribution of the data was charted. All the previous steps were performed using the free software environment for statistical computing and graphics R [60].

\subsection{Index Construction}

Broadly speaking, an index is a measure composed of other variables that allows for the representation of a construct or result [61]; it can be used as a quantitative indicator of the researched idea. Indices can be developed in different ways, however, in the case of SES constructs and health-related indices, the PCA is a variable reduction approach which remains constantly used and is thought to be useful in epidemiological studies, despite its limitations. Howe, Hargreaves and Huttly [62] consider that a PCA "involves replacing a set of correlated variables with a set of uncorrelated 'principal components' which represent unobserved characteristics of the population." Additionally, beyond the method that is used, what will weight on the results of the model seems to be the categorization of the variables [62]. This perspective was taken into account to construct three (3) indices, considering that every time an item is categorized differently, the PCA results change; thus, a total number of 76 items, contemplating the original item and its different forms of categorization, were considered (See Appendix A).

- For what concerns SES: Socio-economic stratification, which in Colombia is a way to classify the residential properties that must receive public services and subsidies according to their social stratum, are established in the Law 142 from 1994 [63]. SEP indicators include the wage reported in the Minimum Legal Wages for the year 2020 in Colombia, the occupational status and the educational level. Evaluation of wealth assets: residing in one's own house (belonging to the individual or to the nucleus of co-habitation, where no rent is to be paid); access to a computer; money for leisure; savings; debts; permanent access to the internet; and covered month (which means the feeling of being able to manage with the available monthly income). Number of people who inhabit the home. The average number for Colombian homes is 3.3 in urban zones and 3.9 in rural zones. Furthermore, $52.7 \%$ of homes with 5 or more people reported incomes below 2 minimum wages [64]. This type of family structure, or cultures that foster familistic societies, can be not so good on an economic level. This is due to the fact that, regardless of the possible social support that these networks provide, economic resources seem to be more associated with living alone instead [65].

- Regarding health: the perception of having a good health, the use of medicines and the body mass index (BMI) were evaluated. In addition, some of the main causes of death and non-communicable diseases were considered as well: cancer, diabetes, hypertension/high blood pressure, dyslipidemia (evaluated through the vector: HDLLDL cholesterol, triglycerides) and cardiovascular diseases. Additionally, diagnosis of a mental/psychological disorder, general self-reported stress and fatigue were taken into account.

- $\quad$ For lifestyle: having a sedentary life; doing sports at least 3 times a week; doing sports at least 30 min every time; smoking; drinking alcohol; self-assessment of one's eating habits; walking; and using a bike were considered. Sleeping hours per day ( $24 \mathrm{~h})$. Regularly sleeping less than $7 \mathrm{~h}$ per night can lead to adverse health conditions, such as 
weight gain and obesity, hypertension, depression, diabetes, heart disease and stroke, and increased risk of death; between 7 and $9 \mathrm{~h}$ could be considered a normal range for young adults and adults, while more than $9 \mathrm{~h}$ could be enough for young adults and for people recovering from sleep debt or suffering from illnesses. Nevertheless, it is still unknown whether sleeping more than $9 \mathrm{~h}$ per night could imply health risks [66].

Additionally, for contrasting the utility of the indices, the following variables were taken into account too:

- $\quad$ RTCs in a dichotomous way No/Yes (0-1): have you ever suffered a traffic crash? Suffering a crash as a road actor, a variable that was considered when the participant was matched in the vector: having a traffic crash, or a crash as a passenger, on a bike, as a pedestrian or as a driver. The variables that compose this vector were also used to study the contrasts.

- $\quad$ RTCs as continuous variable: number of traffic crashes throughout one's life; number of crashes suffered as a passenger in one's life; number of crashes suffered on a bike; number of crashes suffered as a pedestrian; number of crashes suffered as a driver during one's life.

- $\quad$ Age and sex. As several road traffic studies have demonstrated, there are significant differences in the traffic crashes suffered by different age groups [67], by men and women [67], as well as various concerns in the economic and health-related fields [31].

\subsection{Compliance with Ethical Standards}

The present study obtained its ethical approval from the Research Ethics Committee of the University Research Institute on Traffic and Road Safety at the University of Valencia (IRB: E0002080419). Additionally, it complied with the guidelines established by the Code of Ethics and Bioethics of Psychologists [68]. Following this code, participants completed the survey only if they had previously agreed with an informed consent form that emphasized confidentiality and data protection rights, with special attention to the fact that the data would be used only for research purposes, thus encouraging participants to provide sincere answers.

\section{Results}

With these data, the descriptive analyses used to understand the participants' profiles were performed according to sex and income, and they can be consulted in Table 1. In total, 413 women (73.88\%) and 146 men (26.12\%) participated, and their mean (SD) age was 20.83 (2.49) years. In total, 59.3\% of the sample reported having finished their high school studies; Status 3-middle (40.4\%), Status 2-low (41.1\%) and Status 1-low-low (7.5\%), represents $89.05 \%$ of the total sample.

Table 1. Sociodemographic characteristics and information as road actors, crossed by sex and income.

\begin{tabular}{|c|c|c|c|c|c|c|c|}
\hline \multirow[b]{2}{*}{$\begin{array}{c}\text { Variable } \\
\text { Mean (SD) }\end{array}$} & \multirow[b]{2}{*}{ Fr } & \multicolumn{2}{|c|}{ Sex } & \multicolumn{4}{|c|}{ Income SMLMV } \\
\hline & & $\begin{array}{c}\text { Man \% } \\
(n=146)\end{array}$ & $\begin{array}{c}\text { Woman \% } \\
(n=413)\end{array}$ & $\begin{array}{c}\text { None } \\
(n=160)\end{array}$ & $\begin{array}{c}<1 \\
(n=263)\end{array}$ & $\begin{array}{c}1-2 \\
(n=111)\end{array}$ & $\begin{array}{c}>2 \\
(n=27)\end{array}$ \\
\hline Age & & \multicolumn{2}{|c|}{$\chi^{2}=11.645, p=0.009, C=0.143$} & \multicolumn{4}{|c|}{$\chi^{2}=98.227, p<0.001, C=0.386$} \\
\hline $20.83(2.49)$ & & $21.4(2.6)$ & $20.63(2.43)$ & $19.99(2.13)$ & $20.58(2.09)$ & $22.23(2.76)$ & $22.63(3.64)$ \\
\hline 18 & 94 & $11 \mathrm{a}$ & $18.9 \mathrm{~b}$ & $29.4 \mathrm{~b}$ & $12.9 \mathrm{a}$ & $7.2 \mathrm{a}$ & 18.5 \\
\hline $19-21$ & 284 & 47.3 & 51.8 & 48.8 & $60.5 b$ & $36.9 \mathrm{a}$ & $22.2 \mathrm{a}$ \\
\hline $22-24$ & 126 & 26 & 21.1 & 18.8 & 20.5 & $33.3 \mathrm{~b}$ & 18.5 \\
\hline $25-28$ & 57 & $15.8 \mathrm{~b}$ & $8.2 \mathrm{a}$ & $3.1 \mathrm{a}$ & $6.1 \mathrm{a}$ & $22.5 \mathrm{~b}$ & $40.7 \mathrm{~b}$ \\
\hline \multicolumn{2}{|c|}{ Educational level } & & & \multicolumn{4}{|c|}{$\chi^{2}=22.572, p=0.007, C=0.197$} \\
\hline Primary school or lower & 2 & 0 & 0.5 & 0.6 & 0 & 0.9 & 0 \\
\hline High school or technical & 334 & 52.7 & 62 & 61.9 & $54 \mathrm{a}$ & $73.9 \mathrm{~b}$ & $40.7 \mathrm{a}$ \\
\hline University & 220 & 46.6 & 36.6 & 36.9 & $45.2 \mathrm{~b}$ & $24.3 \mathrm{a}$ & 55.6 \\
\hline Postgraduate or PhD & 5 & 0.7 & 1 & 0.6 & $0.8 \mathrm{a}$ & 0.9 & 3.7 \\
\hline
\end{tabular}


Table 1. Cont.

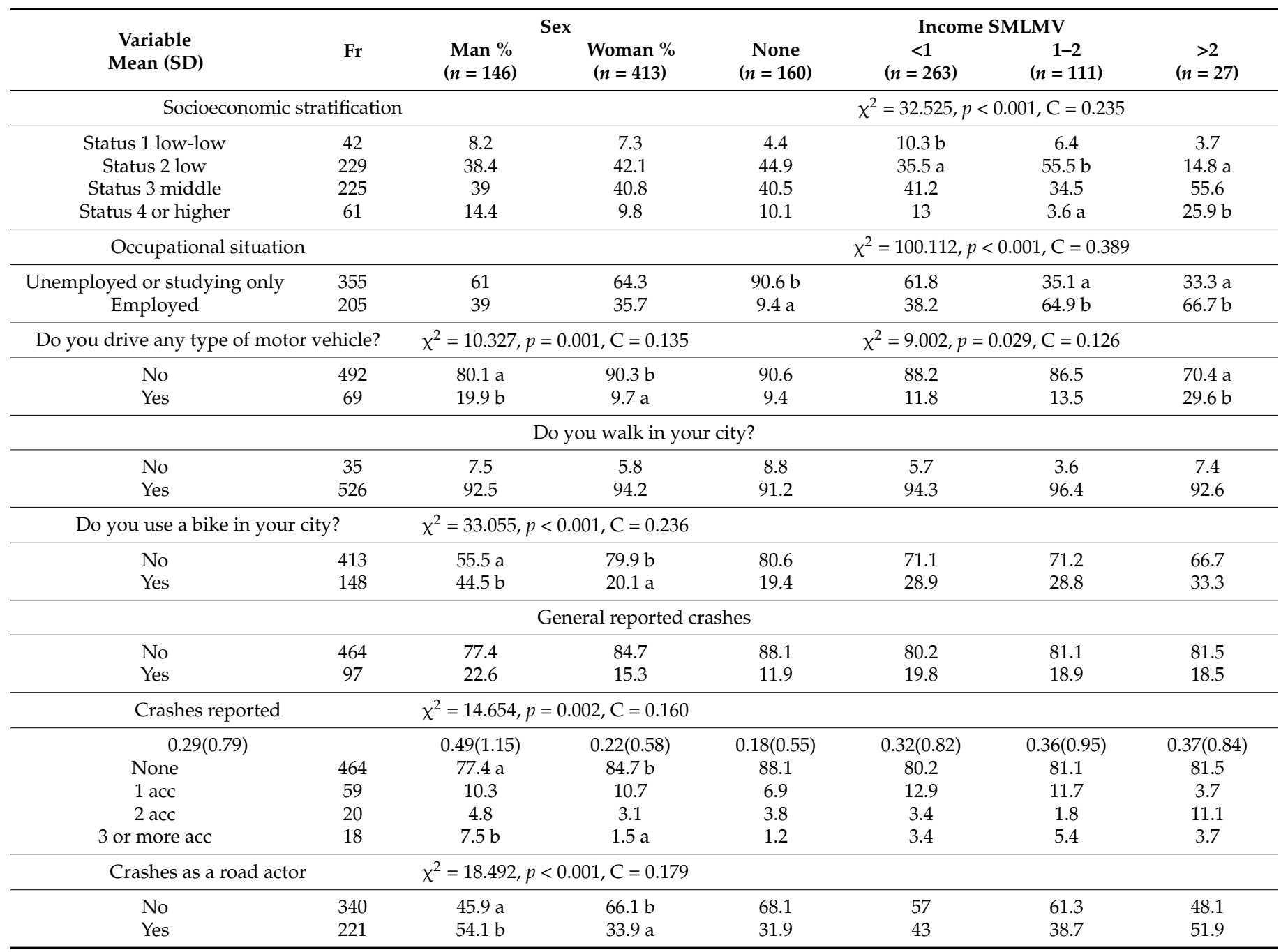

Notations used at the table. SD: Standard deviation; Fr: Frequency; SMLMV: Minimum legal wages in Colombia for the year 2020; $\chi^{2}$ : Chi square, $p$ : $p$-value, C: contingency coefficient; a: Corrected typified residue < -1.96 ; b: Corrected typified residue $>1.96$.

\subsection{PCA Indices Construction}

Variables accounting to equal or more than $95 \%$ in any of the answer categories were discharged. To construct the PCA indices, the subset of variables was scaled, allowing for the use of covariances matrices. The Kaiser-Meyer-Olkin (KMO) factor adequacy was tested to be higher than 0.5 , which is considered acceptable for employing the selected method. Several models were tested, considering 70 possible variables. These were reduced according to their contribution to the final models and to the cluster explaining the possible components, in addition to the related theory. The final components manage to explain around $56.3 \%$ and $67.9 \%$ of the total variance, and they were used to generate three indices: SES, Health and Lifestyle. The respective loadings with an absolute cutoff of $|0.34|$ for components with eigenvalues $\geq 1$ are displayed in Table 2. Missing data were omitted in the final model in order not to affect its predictive value (see Table 2).

The indices were constructed through the sum and ponderation of the variance explained by each eigenvalue $\geq 1$, to be then re-scaled within a $0-1$ range. For SES and Lifestyle indices, a value equal to 1 corresponds to the most favorable socioeconomic status and to the best lifestyle conditions, respectively. For what concerns the health index, 0 represents a lack of unfavorable health conditions and 1 represents the presence of illness. Some works suggest considering only the first component of the PCA (Comp.1) to construct the indices, and, therefore, the Comp.1 of each model was tested in contrast with 
another index equivalent to the sum and ponderation of all components with eigenvalues $\geq 1$. However, the relations explained only by the Comp.1 were not found to provide better or worse contrast results, which is why we chose, as final indices, those that ponder components in order to increase the variance explained by the model. The indices were also categorized in terciles that were Low $(<0.43)$, Average $(0.43-0.61)$, and High $(>0.61)$ in the case of SES; for what concerns the Lifestyle, they were Unhealthy $(<0.44)$, Average (0.44-0.81), Healthy (>0.81); and regarding Health, they corresponded to Good Health $(>0.28)$, Average Health (0.20-0.28), and Poor Health $(<0.20)$.

Table 2. Principal Component Analysis for three indices: Socioeconomic, Health and Lifestyle.

\begin{tabular}{|c|c|c|c|c|c|}
\hline Variable & Comp.1 & Comp.2 & Comp.3 & Comp.4 & Comp.5 \\
\hline \multicolumn{6}{|l|}{ Socioeconomic status SES $(n=556)$} \\
\hline Occupational situation (does not work/student-works) & 0.32 & 0.53 & 0.03 & 0.01 & 0.01 \\
\hline Socioeconomic stratification (low-low, low, middle, high) & 0.31 & -0.27 & -0.14 & 0.34 & 0.59 \\
\hline Educational level (low, intermediate, high, high-high) & 0.09 & -0.17 & 0.66 & 0.46 & -0.31 \\
\hline Income (continuous in Colombian pesos) & 0.34 & 0.37 & -0.06 & 0.41 & -0.14 \\
\hline Residing in one's own house (No/Yes) & 0.14 & -0.17 & -0.7 & 0.33 & -0.45 \\
\hline Having access to a computer (No/Yes) & 0.35 & -0.07 & 0.08 & -0.49 & -0.49 \\
\hline Money for leisure (No/Yes) & 0.44 & -0.14 & 0.21 & 0.03 & 0.11 \\
\hline Having debts (reversed No/Yes) & -0.15 & -0.57 & 0.02 & 0.06 & -0.13 \\
\hline Access to the internet (No/Yes) & 0.38 & -0.16 & -0.08 & -0.39 & 0.25 \\
\hline Covered month (No/Yes) & 0.42 & -0.26 & 0.01 & -0.04 & -0.08 \\
\hline Eigenvalue & 1.88 & 1.63 & 1.08 & 1.03 & 0.85 \\
\hline Proportion of variance & $18.87 \%$ & $16.29 \%$ & $10.78 \%$ & $10.30 \%$ & $8.52 \%$ \\
\hline Cumulative variance & $18.87 \%$ & $35.16 \%$ & $45.95 \%$ & $56 \%$ & $64.78 \%$ \\
\hline \multicolumn{6}{|l|}{ Health $(n=557)$} \\
\hline BMI (continuous in $\mathrm{kg} / \mathrm{mts}^{2}$ ) & 0.04 & 0.55 & 0.15 & 0.58 & 0.57 \\
\hline Hypertension (No/Yes matched in the vector: hypertension and high blood pressure) & -0.01 & 0.55 & 0.09 & -0.75 & 0.24 \\
\hline Dyslipidemia (No/Yes matched in the vector: cholesterol, LDL, HDL, triglycerides) & -0.18 & 0.53 & 0.2 & 0.21 & -0.76 \\
\hline Diagnosis of a mental/psychological disorder (No/Yes) & 0.27 & 0.32 & -0.65 & -0.11 & -0.12 \\
\hline Perception of good health (No/Yes) & 0.41 & 0.04 & -0.51 & 0.21 & -0.05 \\
\hline General stress (assumed as continuous 0-10) & 0.61 & 0.05 & 0.33 & -0.04 & -0.11 \\
\hline General fatigue (assumed as continuous 0-10) & 0.6 & -0.09 & 0.37 & -0.05 & -0.07 \\
\hline Eigenvalue & 1.81 & 1.23 & 1.07 & 0.93 & 0.85 \\
\hline Proportion of variance & $25.92 \%$ & $17.59 \%$ & $15.33 \%$ & $13.31 \%$ & $12.16 \%$ \\
\hline Cumulative variance & $25.92 \%$ & $43.51 \%$ & $58.84 \%$ & $72.15 \%$ & $84.31 \%$ \\
\hline \multicolumn{6}{|l|}{ Lifestyle $(n=561)$} \\
\hline Having a sedentary life (reversed No/Yes) & 0.57 & 0.02 & 0.08 & 0.66 & 0.48 \\
\hline Exercising 3 times per week (No/Yes) & 0.58 & 0.12 & 0.03 & 0.07 & -0.8 \\
\hline Exercising for 30 min every time (No/Yes) & 0.56 & 0.09 & 0.02 & -0.74 & 0.36 \\
\hline Smoking (reversed No-ex/Yes) & 0.14 & -0.67 & -0.72 & 0 & -0.03 \\
\hline Drinking alcohol (reversed No-ex/Yes) & 0.05 & -0.72 & 0.68 & -0.07 & -0.05 \\
\hline Eigenvalue & 2.19 & 1.2 & 0.78 & 0.47 & 0.36 \\
\hline Proportion of variance & $43.88 \%$ & $24.06 \%$ & $15.54 \%$ & $93.60 \%$ & $71.60 \%$ \\
\hline Cumulative variance & $43.88 \%$ & $67.95 \%$ & $83.49 \%$ & $92.84 \%$ & $100 \%$ \\
\hline
\end{tabular}

Loadings with an absolute cutoff of $|0.34|$ are shown in bold.

\subsection{Means and Frequency Contrast}

To explore the behavior of the indices categorized in terciles, the Chi-square test of Independence was employed and reported, together with the adjusted standardized residuals, where values higher than 1.96 indicate more cases than expected, while values lower than 1.96 indicate fewer cases than expected. The effect size is reported through the contingency coefficient (see Table 3). To begin with the SES index, statistically significant differences were found in the driving task. It is attention-worthy how there are more cases than expected presenting a high SES in the case of those who drive. On the other hand, suffering a crash as a pedestrian presents differences as well; specifically, people with a higher SES report more crashes like these, while an average SES implies fewer people who have suffered a crash as pedestrians. For what concerns the Health Index, no significant differences were found. 
Table 3. Results for chi-square test of Independence.

\begin{tabular}{|c|c|c|c|c|c|c|c|c|c|c|}
\hline \multirow[b]{2}{*}{$\begin{array}{l}\text { Variable } \\
\text { Mean(SD) }\end{array}$} & \multirow[b]{2}{*}{ Fr } & \multicolumn{3}{|c|}{ SES Index 0.52(0.19) } & \multicolumn{3}{|c|}{ Health Index 0.27(0.15) } & \multicolumn{3}{|c|}{ Lifestyle Index 0.59(0.28) } \\
\hline & & $\begin{array}{c}\text { Low } \\
(n=186)\end{array}$ & $\begin{array}{l}\text { Average } \\
(n=183)\end{array}$ & $\underset{(n=187)}{\text { High }}$ & $\begin{array}{c}\text { Good } \\
(n=187)\end{array}$ & $\begin{array}{l}\text { Average } \\
(n=186)\end{array}$ & $\begin{array}{c}\text { Poor } \\
(n=184)\end{array}$ & $\begin{array}{l}\text { Unhealthy } \\
(n=127)\end{array}$ & $\begin{array}{l}\text { Average } \\
(n=269)\end{array}$ & $\begin{array}{l}\text { Healthy } \\
(n=165)\end{array}$ \\
\hline \multicolumn{2}{|c|}{ Health Index } & & & & & & & \multicolumn{3}{|c|}{$\chi^{2}=15.081, p=0.005, C=0.162$} \\
\hline Good & 187 & 23.6 & 33.1 & 42.1 & 23.6 & 33.1 & 42.1 & $23.6 \mathrm{a}$ & 33.1 & $42.1 \mathrm{~b}$ \\
\hline Average & 186 & 33.1 & 33.5 & 33.5 & 33.1 & 33.5 & 33.5 & 33.1 & 33.5 & 33.5 \\
\hline Poor & 184 & 43.3 & 33.5 & 24.4 & 43.3 & 33.5 & 24.4 & $43.3 \mathrm{~b}$ & 33.5 & $24.4 \mathrm{a}$ \\
\hline \multicolumn{2}{|c|}{$\begin{array}{l}\text { Drive any type of } \\
\text { motor vehicle }\end{array}$} & \multicolumn{3}{|c|}{$\chi^{2}=7.569, p=0.023, C=0.116$} & & & & & & \\
\hline No & 492 & 91.4 & 89.1 & $82.4 \mathrm{a}$ & 87.2 & 88.7 & 87.5 & 88.2 & 88.5 & 86.1 \\
\hline Yes & 69 & 8.6 & 10.9 & $17.6 \mathrm{~b}$ & 12.8 & 11.3 & 12.5 & 11.8 & 11.5 & 13.9 \\
\hline \multicolumn{11}{|c|}{ Do you walk in your city? } \\
\hline No & 35 & 6.5 & 5.5 & 7 & 7 & 4.8 & 6.5 & 7.1 & 6.7 & 4.8 \\
\hline Yes & 526 & 93.5 & 94.5 & 93 & 93 & 95.2 & 93.5 & 92.9 & 93.3 & 95.2 \\
\hline \multicolumn{5}{|c|}{ Do you use a bike in your city? } & & & & \multicolumn{3}{|c|}{$\chi^{2}=18.778, p<0.001, C=0.180$} \\
\hline No & 413 & 73.7 & 76.5 & 72.2 & 70.1 & 74.2 & 76.1 & 77.2 & 79.6 & $61.2 \mathrm{a}$ \\
\hline Yes & 148 & 26.3 & 23.5 & 27.8 & 29.9 & 25.8 & 23.9 & 22.8 & 20.4 & $38.8 \mathrm{~b}$ \\
\hline \multicolumn{3}{|c|}{ Reported crashes } & & & & & & \multicolumn{3}{|c|}{$\chi^{2}=8.866, p=0.012, C=0.125$} \\
\hline No & 464 & 87.1 & 79.2 & 81.3 & 80.2 & 83.3 & 84.8 & $74 \mathrm{a}$ & 85.9 & 84.2 \\
\hline Yes & 97 & 12.9 & 20.8 & 18.7 & 19.8 & 16.7 & 15.2 & $26 \mathrm{~b}$ & 14.1 & 15.8 \\
\hline \multicolumn{3}{|c|}{ Crashes riding a bike } & & & & & & \multicolumn{3}{|c|}{$\chi^{2}=11.228, p=0.004, C=0.140$} \\
\hline No & 487 & 87.6 & 89.6 & 82.9 & 84.5 & 85.5 & 90.2 & 89.8 & $90 \mathrm{a}$ & $79.4 \mathrm{a}$ \\
\hline Yes & 74 & 12.4 & 10.4 & 17.1 & 15.5 & 14.5 & 9.8 & 10.2 & $10 \mathrm{~b}$ & $20.6 b$ \\
\hline \multicolumn{2}{|c|}{ Crash as a pedestrian } & \multicolumn{3}{|c|}{$\chi^{2}=10.322, p=0.006, C=0.169$} & & & & & & \\
\hline No & 281 & 79.7 & 86.2 b & $68.2 \mathrm{a}$ & 79.3 & 77.6 & 80.3 & 75.4 & 77 & 84.5 \\
\hline Yes & 74 & 20.3 & $13.8 \mathrm{a}$ & $31.8 \mathrm{~b}$ & 20.7 & 22.4 & 19.7 & 24.6 & 23 & 15.5 \\
\hline \multicolumn{2}{|c|}{ Crash as a driver } & & & & & & & \multicolumn{3}{|c|}{$\chi^{2}=11.804, p=0.003, C=0.382$} \\
\hline No & 45 & 68.8 & 45 & 75.8 & 58.3 & 71.4 & 65.2 & $40 \mathrm{a}$ & 58.1 & $91.3 \mathrm{~b}$ \\
\hline Yes & 24 & 31.2 & 55 & 24.2 & 41.7 & 28.6 & 34.8 & $60 \mathrm{~b}$ & 41.9 & $8.7 \mathrm{a}$ \\
\hline \multicolumn{2}{|l|}{ Sex } & & & & & & & \multicolumn{3}{|c|}{$\chi^{2}=6.567, p=0.037, C=0.108$} \\
\hline Man & 146 & 22.6 & 26.5 & 29.9 & 31.6 & 25.8 & 21.4 & 27 & $21.6 \mathrm{a}$ & $32.7 \mathrm{~b}$ \\
\hline Woman & 413 & 77.4 & 73.5 & 70.1 & 68.4 & 74.2 & 78.6 & 73 & $78.4 \mathrm{~b}$ & $67.3 \mathrm{a}$ \\
\hline \multicolumn{11}{|l|}{ Age } \\
\hline 18 & 94 & 16.7 & 15.3 & 17.1 & 20.3 & 18.3 & 11.4 & 13.4 & 18.2 & 17 \\
\hline $19-21$ & 284 & 50 & 50.8 & 51.3 & 47.1 & 50 & 54.9 & 57.5 & 47.6 & 50.3 \\
\hline $22-24$ & 126 & 23.7 & 21.9 & 22.5 & 24.1 & 22.6 & 21.2 & 23.6 & 21.2 & 23.6 \\
\hline $25-28$ & 57 & 9.7 & 12 & 9.1 & 8.6 & 9.1 & 12.5 & 5.5 & 13 & 9.1 \\
\hline
\end{tabular}

Notations used at the table. SD: Standard deviation; Fr: Frequency; $\chi^{2}$ : Chi square, $p: p$-value, C: contingency coefficient; a Corrected typified residue $<1.96$; b Corrected typified residue $>16$.

On the other hand, the Lifestyle index shows differences in comparison with the Health index, since the adjusted standardized residuals show more cases of poor health than expected in the case of the unhealthy lifestyle group; also, there were fewer cases of poor health in the healthy lifestyle group. Differences in the use of bikes show that there are fewer cases of people not using bikes in the healthy lifestyle group. Regarding bike crashes, more cases than expected were found in the healthy lifestyle too, for those who were involved in this type of crash. The self-reported crashes also showed significant differences: there were more cases than expected when considering unhealthy lifestyles. The lifestyle index also presented differences with the crashes suffered as a driver, finding 
more cases than expected in the unhealthy lifestyle category and in those who suffered the crash, and fewer cases in the healthy lifestyle group. Finally, differences were found in the sex variable, too: there are fewer women with a healthy lifestyle in comparison with the group of men (see Table 3).

For what concerns the continuous variables, Student's $t$-test for independent samples was also tested (see Table 4), considering crash rates and mobility as contrasting variables. For what concerns the SES index, it was found that those who drive presented an average SES higher than those who do not. There are no mean differences related to the Health index. Regarding the lifestyle index, it was found that those who reported suffering a crash had a lower lifestyle mean; those who suffered crashes as drivers also presented a lower mean; and, finally, those who rode a bike had a lifestyle mean that was higher than those who did not.

Table 4. Mean comparisons for independent samples.

\begin{tabular}{|c|c|c|c|c|c|c|c|c|c|c|}
\hline Contrasting Variable & Continuous & $\begin{array}{l}\text { Mean } \\
\text { No/Man }\end{array}$ & $\begin{array}{c}\text { Mean } \\
\text { Yes/Woman }\end{array}$ & t.test & df & C.low & C.high & $p$ & p.ad & EF \\
\hline Reported crashes $(\mathrm{No}=464$, & Lifestyle Index & 0.60 & 0.52 & 2.69 & 139.83 & 0.02 & 0.14 & 0.008 & 0.027 & 0.08 \\
\hline Yes $=97)$ & Age & 20.69 & 21.53 & -2.93 & 134.97 & -1.40 & -0.27 & $<0.001$ & 0.015 & -0.84 \\
\hline \multirow[t]{2}{*}{$\begin{array}{l}\text { Crash as a road actor } \\
(\mathrm{No}=340, \mathrm{Yes}=221)\end{array}$} & Age & 20.53 & 21.30 & -3.54 & 447.00 & -1.19 & -0.34 & $<0.001$ & $<0.001$ & -0.77 \\
\hline & Crash as a driver & 0.22 & 0.84 & -4.73 & 68.00 & -0.95 & -0.39 & $<0.001$ & $<0.001$ & -0.67 \\
\hline Drive any type of motor & Age & 20.67 & 21.99 & -3.73 & 82.99 & -2.01 & -0.61 & $<0.001$ & 0.002 & -1.31 \\
\hline \multirow[t]{2}{*}{ vehicle $(\mathrm{No}=492$, Yes $=69)$} & Income in SMLMV & 0.08 & 0.23 & -2.94 & 75.71 & -0.26 & -0.05 & 0.004 & 0.017 & -0.15 \\
\hline & SES Index & 0.51 & 0.58 & -2.39 & 83.23 & -0.12 & -0.01 & 0.019 & 0.049 & -0.06 \\
\hline $\begin{array}{c}\text { Crash as a driver }(\mathrm{No}=45, \\
\text { Yes }=24)\end{array}$ & Lifestyle Index & 0.66 & 0.43 & 3.31 & 55.93 & 0.09 & 0.36 & 0.002 & 0.009 & 0.22 \\
\hline \multirow{2}{*}{$\begin{array}{l}\text { Using a bike in the city } \\
(\mathrm{No}=413, \text { Yes }=148)\end{array}$} & Age & 20.58 & 21.54 & -3.92 & 242.39 & -1.44 & -0.48 & $<0.001$ & 0.001 & -0.96 \\
\hline & Lifestyle Index & 0.57 & 0.65 & -3.16 & 261.10 & -0.14 & -0.03 & 0.002 & 0.011 & -0.08 \\
\hline \multirow{3}{*}{$\begin{array}{c}\text { Sex }(\text { Man = 146, } \\
\text { Woman = 413) }\end{array}$} & Crash riding a bike & 0.65 & 0.15 & 4.18 & 173.96 & 0.27 & 0.74 & 0.000 & 0.001 & 0.50 \\
\hline & Reported crashes & 2.18 & 1.41 & 2.79 & 171.50 & 0.08 & 0.47 & 0.006 & 0.038 & 0.28 \\
\hline & Age & 21.40 & 20.63 & 3.11 & 240.01 & 0.28 & 1.25 & 0.002 & 0.019 & 0.77 \\
\hline
\end{tabular}

Notation $t$-test: T statistic; df: Degree of freedom; C.low: confidence interval low; C.high: confidence interval high; $p: p$-value, $p$.ad: $p$ value adjusted; EF: effect size.

Finally, Figure 1 shows a violin plot for the indices that display the variables' distribution depending on the reported crashes and on the sex variables (as an example of the possible distributions the indices could have across the participants' features). The figure allows us to visualize the predictive power of the indices, observing that the lifestyle index is the one adjusting to the data curve in the most adequate way. 
Have you ever suffered a traffic crash?
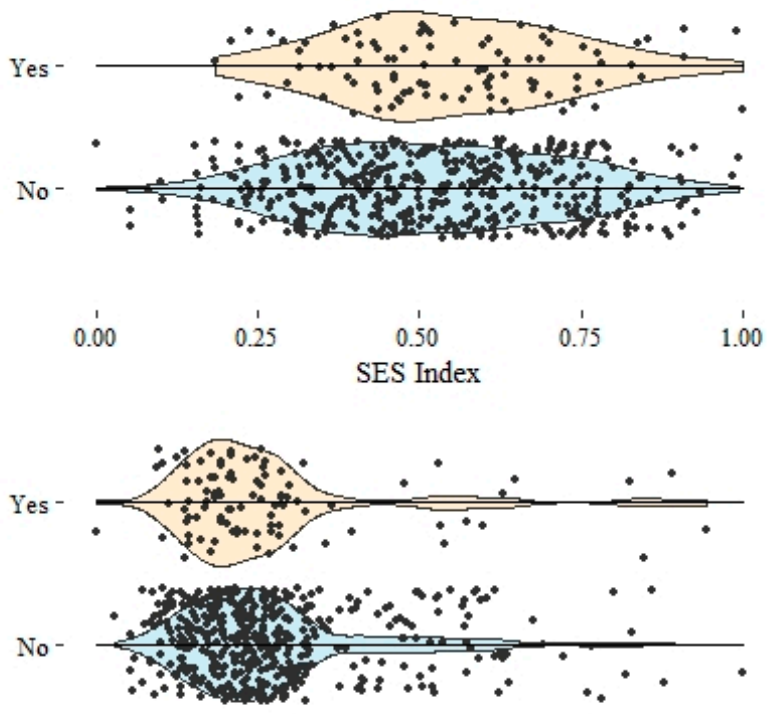

0.00

$$
0.25
$$

$$
0.50
$$

Health Index

\subsection{5}
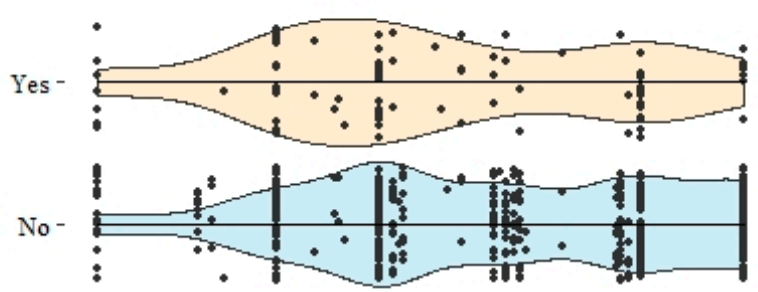

0.00

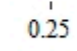

0.50

Lifestyle Index
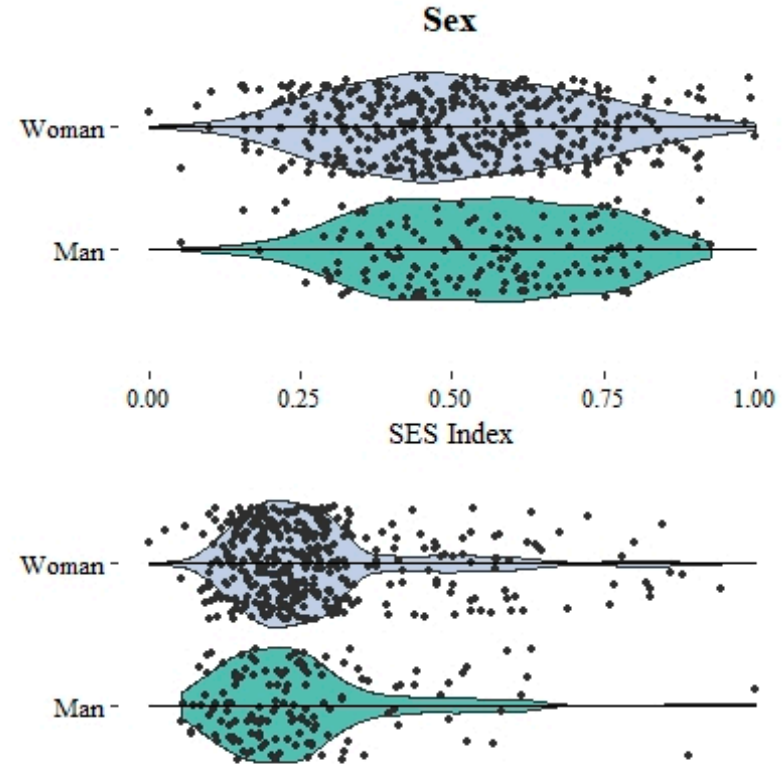

$0.00 \quad 0.25$

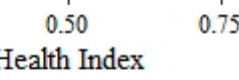

1.00

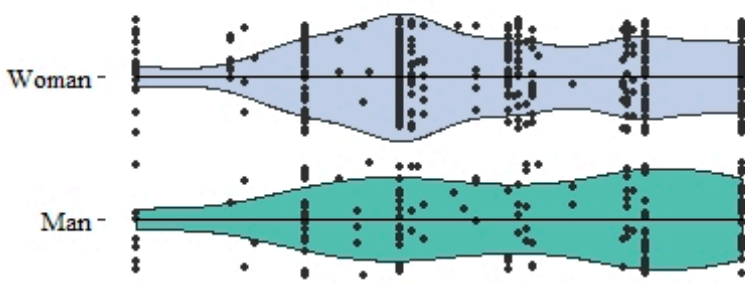

$\stackrel{1}{0} 00$

0.25

0.50

0.75

Lifestyle Index

Figure 1. Violin plot of the indices for reported crashes and sex.

\section{Discussion}

Understanding that developing countries are severely affected by RTCs and that this issue must be approached from a multi-dimension and interdisciplinary perspective, this work has proposed the need of studying crash rates and mobility patterns in young Colombians through SES, health and lifestyle as predictors of psychosocial risk factors. To our knowledge, this is the first study of this type that was ever performed in Colombia. By means of a reductive approach and to explain between $56.3 \%$ and $67.9 \%$ of the variance, three indices were constructed: SES, Health and Lifestyle, since the evidence appoints them as determinant elements to be considered when comprehending who suffers RTCs and why.

To begin with, the variables reduction led us to discharge a total of 54 variables, leaving three models composed of 10 variables (SES), 7 variables (Health) and 5 variables (Lifestyle). This reduction also allowed for a better understanding of how, despite the fact that there are variables highlighted in other countries that we expected would be valuable in these models too (such as the number of people in the home, or the hours of sleep), this did not apply to the population of young Colombians, emphasizing the idea that it is necessary to perform studies focused on the specific issues of each country [69]. 


\subsection{Mobility and RTCs Patterns of Young Colombians}

To begin with, this study points out some interesting mobility patterns. The majority of young people report walking in their city $(93.76 \%)$, but their participation as road actors starts to decrease with the use of vehicles; only $26.38 \%$ of them use a bike, and even fewer drive a motor vehicle (12.3\%), mostly male drivers. Overall, $17.29 \%$ of them report that they have been involved in a traffic crash at least once in their life. However, the proportion of those who have been involved in a crash, regardless of their road role, increased up to $39.9 \%$ : this leads us to acknowledge that, as other authors have already pointed out [48], young people are indeed at risk for dangerous situations on the road. Additionally, in both cases men reported a higher number of crashes, following the gender-related tendencies associated with RTCs [70,71].

\subsection{Social and Health Determinants in Young Colombians' RTCS \\ 4.2.1. Socioeconomic status (SES) and Young Colombians}

SES is a determinant of health, as well as of the risky and/or protective actions that a person performs when living. Vulnerable SES and health imply severe detriments for the individual's quality of life, and the proportion of these inequalities are highly present in developing countries. The problem is that, as some studies have pointed out, the more crashes happen, the bigger the social and economic burden becomes for a country [9,72]. A heavier burden probably corresponds to a lower investment in the development of laws and in the work on road safety, which is a reason why, in addition to the deaths associated with this phenomenon, we are facing a political and economic issue that negatively feeds back on itself. It is not a surprise that vulnerable subjects could be more involved in crashes in countries with poor or still-developing policies, as we were able to verify with this work.

It was found that the indicators of young Colombians were associated with detrimental social conditions. Following the Colombian socio-economic classification, around $48.65 \%$ of participants are below the 3rd (middle-low) status, and the debt variable had a considerable weight on the third PCA component. However, the educational factor, among others, was slightly higher than expected in this population, counterbalancing the model so that the index's terciles point out groups that are more or less similar. This is probably due to the participants mostly living in the country's capital, and to them being financially supported by their families [73], a support that could also have an influence on the health status through the reduction of psychological stressors [74]. However, this variable did not have any weight on the SES model.

Generally speaking, this index highlighted interesting relations (though fewer than expected) contrasting with variables related to young drivers. To begin with, it was found that those who drive are more associated with high SES, and the index mean is higher for them than it is for those who do not drive. This could be explained by the fact that driving allows the person to move more easily in the city, or even to work more easily, and that, of course, having access to a vehicle is linked to an economy that accumulates capital [75]. As we have said before, the driving task is different depending on sex: men drive more, and those who drive report higher salaries.

On the other hand, those who have experienced crashes as a pedestrian are in the high SES tercile. This provides evidence to reject our initial hypothesis, in which we considered that high SES would present fewer relations with crashes, which is a source of concern not only considering that pedestrians are the most vulnerable road actors [76], but also because, according to the theory, high SES should correspond to a protective factor. In this case, beyond the SES the road safety conditions of Colombia should be taken into account, in addition to the alarming death and injury rates of RTCs and the walkability perception [77].

\subsubsection{Health, Lifestyle and Young Colombians}

Moving on to the health index, it did not show significant contrasts in the present analysis. However, we can notice in Figure 1, in the part addressing the contrast with crashes, 
how the proposed model includes the majority of the cloud data within its distribution. The non-existence of significant relations is not necessarily a reason for discharging the construct of RTCs' study: on the contrary, we believe that the results are caused by the population being young, and by the prevalence of illnesses being quite low, as it can be seen in the index's terciles. In addition, research on young drivers' health is more related to their tendency to drink and consume substances [78], which corresponds rather to the field of healthy lifestyle habits (without being excluded from the health sphere).

Actually, it was found that the lifestyle index presents differences from the health index, and there are more cases than expected presenting a poor health in the high/good lifestyle category. However, the relations between this index and mobility seem to be more important (assuming that young people do not get sick so often). To begin with, those who use the bike have a healthy lifestyle and represent a higher proportion of the highest index. This result is important in terms of sustainable mobility, but it also represents benefits for physical [79] and mental health, and it can even have therapeutic effects on some specific populations [80,81]. Nevertheless, it was found that people with a healthier lifestyle suffer more crashes when riding a bike. This is quite concerning, since the message of mobility in the country's context would then be against the promotion of health. As Evans states: "many people say they would cycle more if the roads were safer-the biggest deterrent to more cycling is high traffic speeds and volumes. There is obviously a vicious circle to be reversed here" [79]. Even so, the study of cyclists' behavior must be deepened, since they are road actors too, and they could contribute greatly to the occurrence of crashes.

On the other hand, and complementarily, it was found that those reporting that they have suffered RTCs have an unhealthier lifestyle, and, in addition, drivers also have one of the unhealthiest lifestyles. This result is consistent with the findings of other countries and age groups, where it was concluded that driving can even be considered a sedentary activity: driving versus walking [82]. As a sedentary activity, driving can lead to unhealthy habits that are then quite difficult to change [83], with undesirable effects in the shortand long-term.

Finally, the sex and age variables showed important differences that, as we have seen, mark some of the patterns of SES and mobility. It was also found that men are those who keep the healthiest life habits in comparison to women, as other works have shown [84], in addition to having a higher mean of bike crashes. Clearly, we have some risky dynamics at play for young males in Colombia, associated with crash rates. However, this applies to women too, especially in terms of their lower participation in road life and their less healthy life habits. Clearly, a gender perspective must be taken into account in order for women to become more active mobility agents, and for men to be less prone to suffer RTCs. For what concerns age, groups older than 21 engage with the road more, they drive more, they use bikes more, but they also suffer more crashes.

As our results suggest, the work that must be carried out in the country is deep. Joining the same call for action as other authors in what concerns youth [85,86], protecting young Colombians from RTCs must be a priority. It is essential to ensure that they have favorable socioeconomic and psychosocial conditions for their development as well, always following a gender perspective. On the other hand, being active in mobility cannot be a synonym of suffering crashes. If a country aims at enhancing mobility and fostering the use of alternative transport means, such as bikes, it must protect its road actors and provide them with safe contexts so that people will take on an active mobility role through the care of health [87].

\section{Conclusions}

As a result of this research, we now know that SES, Health and Lifestyle as constructs follow a special cluster in the case of young Colombians, and variables highlighted in other countries were not significant in the case of this population. Moreover, sensitive socioeconomic conditions are quite common in this country, and there is a situation of 
social and economic vulnerability for young people, who, interestingly enough, present high levels of education.

One of the achievements of this study was the construction of three models that allow for the generation of SES, Health and Lifestyle indices in the population of young Colombians, which provide information on the crashes and mobility patterns they have, as well as on differences between groups. The main findings were: (1) drivers are associated with higher SES and driving. The action of driving is associated with higher incomes. High SES is not necessarily associated with protection, since pedestrians belonging to this group report higher crash rates; (2) the prevalence of illnesses is low, and it does not affect mobility or crash rates in this population; (3) people with a better lifestyles use bikes more and report more crashes when using them. Unhealthier lifestyles are associated with more RTCs, and with the driving task; (4) sex and age do establish SES, lifestyle and mobility patterns. Men keep healthier life habits than women, they drive more, they use the bike more, but they also report more crashes than women. Women participate less in the road life, and they have less healthy habits. Finally, the results allow us to draw the conclusion that protective factors such as a high SES and a healthier lifestyle are associated with RTCs in this population, and the age group over 21 engages with the road more, they drive more, they use the bike more, but they also suffer more crashes.

Finally, even though some results may seem obvious, they had not been reported yet; and this is a payoff when working on the RTCs prevention of young Colombians. Additionally, we hope that this work will leave the readers with more questions than answers, and, thinking of the results, we would like to draw the attention to the following interrogatives: is not encouraging people to have a better lifestyle through exercise the objective of health prevention policies? Is not leading us to more sustainable and equal cities the objective of mobility? Then why should taking care of one's health and cities end up being a risk for young people? The work that is left now consists of further researching the population of drivers and non-drivers in order to answer these questions.

\section{Limitations and Future Research}

Despite the efforts that were made, the analyses we performed could present limitations, and the existence of confounding variables must be evaluated through other methods. Moreover, the size of the sample must be increased for future applications, not only to widen the number of participants, but also to include people from other geographical places in the country, which would diminish the limitations when researching a developing country [69]. In addition to this, future studies will need to obtain more funding, with the aim of performing samplings that are proportional to age, gender and road users (specially drivers).

Even though the constructed indices present an acceptable percentage of the explained variance, the construction and proposal of models that may explain the SES, health and lifestyle associated with young Colombians with more power must be fostered. In addition to this, other conceptual models for the construction of indices should be considered, for instance, a cumulative proposal instead of a reductive one for the model construction [88].

We hope that the results of this work will be useful for understanding the dynamics associated with RTCs in a developing country, and, moreover, with a population group that is at risk. The work of variable reduction that we have performed can be useful for future studies so it they will reduce the application time in what concerns the sociodemographic variables and allow for focus on deepening the researched topics. Additionally, these indices can be extended to the research of other issues since their construction does not depend on mobility or crash variables, but rather used them for contrast. Regarding future research associated with this study, it is worth highlighting the necessity to improve the health index and its predictive value. In future works, we hope to collect data that go beyond self-reports, especially in what concerns health factors, through quick check-ups and revisions of the participants' medical history, together with visiting the participants' homes in order to contrast the socioeconomic information. We hope to do this with at least one 
subsample, considering the economic and ethical implications. Finally, it would be useful to consider the severity and nature of RCTs for implementing specific prevention strategies.

Author Contributions: Conceptualization, A.S.; data curation, A.S., and J.Q.M.; formal analysis, A.S. and J.Q.M.; investigation, A.S. and F.A.; methodology, A.S.; project administration, A.S., L.M.; resources, F.A., L.M.; software, A.S. and J.Q.M.; supervision, F.A., L.M.; visualization, A.S.; writingoriginal draft, A.S., J.Q.M., F.A., L.M.; writing-review \& editing, A.S., J.Q.M., F.A., L.M. The corresponding author attests that all listed authors meet authorship criteria and that no others meeting the criteria have been omitted. All authors have read and agreed to the published version of the manuscript.

Funding: This research has not received any specific grant from any funding agency in the public, commercial or not-for-profit sectors.

Institutional Review Board Statement: The study was conducted according to the guidelines of the Declaration of Helsinki, and approved by the Research Ethics Committee of the University Research Institute on Traffic and Road Safety of the University of Valencia (IRB: E0002080419, 26/03/2019).

Informed Consent Statement: Informed consent was obtained from all subjects involved in the study.

Data Availability Statement: The datasets and code used and/or analyzed in the present study are available from the corresponding author on reasonable request.

Acknowledgments: We would like to Runa Falzolgher for helping with the English language and Mayte Duce for the revision of the text.

Conflicts of Interest: The authors declare that the research was conducted in the absence of any commercial or financial relationships that could be construed as a potential conflict of interest.

\section{Appendix A}

In this appendix the items considered for the elaboration of the Socioeconomic Status (SES), Health and Lifestyle indices are presented. Taking into account that the categorization of items is important for the Principal Component Analysis (PCA) results, here the different categorization forms assessed in this research are presented, resulting in a total number of 76 possible items, considering that every time an item is categorized differently, the PCA results change. Table A1 shows the items related to SES; Table A2 shows those related to health; and Table A3 shows those related to lifestyle.

If the objective is to reproduce the methodology, please consider the following aspects: (1) Consult the theory related to the population and grounding in categories that others have already built, but also propose your own categories, depending on the researcher's intuition on the data, and compare the results using each categorized item; (2) when some categories represent $95 \%$ of the answers, this item must be rejected from the analysis, since it does not present variance in the population; (3) be careful with the items' directionality, they must all coincide; (4) remember to standardize the items, so that they will all belong to the same scale and you will be able to compare them when performing the principal components analysis (PCA). 
Table A1. Possible variables and categorization for socioeconomic status (SES). Directionality: 0 is the worst/most unfavorable socioeconomic condition.

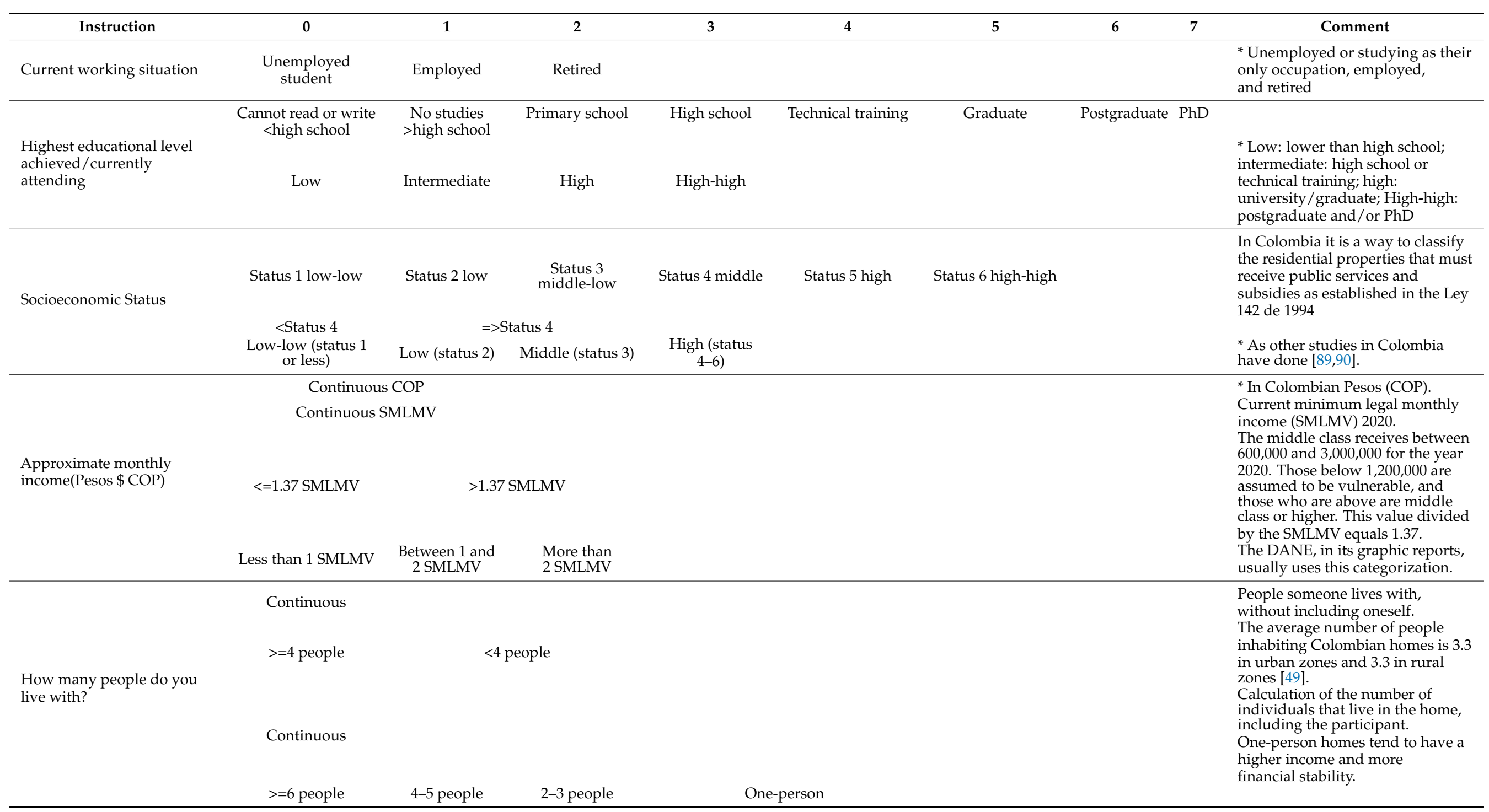


Table A1. Cont.

\begin{tabular}{|c|c|c|c|c|c|c|c|c|c|}
\hline Instruction & 0 & 1 & 2 & 3 & 4 & 5 & 6 & 7 & Comment \\
\hline $\begin{array}{l}\text { Lives in one's own } \\
\text { house EBC1 }\end{array}$ & No & Yes & & & & & & & $\begin{array}{l}{ }^{*} \text { Belonging to the individual or to } \\
\text { the nucleus of co-habitation, where } \\
\text { no rent is to be paid. }\end{array}$ \\
\hline Owns a car EBC2 & No & Yes & & & & & & & $\begin{array}{l}\text { Belonging to the individual or to } \\
\text { the nucleus of co-habitation. }\end{array}$ \\
\hline Cellphone EBC3 & No & Yes & & & & & & & \\
\hline Personal computer EBC4 & No & Yes & & & & & & & * \\
\hline Money for leisure EBC5 & No & Yes & & & & & & & * \\
\hline Paid vacation EBC6 & No & Yes & & & & & & & \\
\hline Savings EBC7 & No & Yes & & & & & & & \\
\hline Access to the Internet EBC9 & No & Yes & & & & & & & \\
\hline Covered month EBC10 & No & Yes & & & & & & & $\begin{array}{l}{ }^{*} \text { Which means the feeling of being } \\
\text { able to manage with the available } \\
\text { monthly income. }\end{array}$ \\
\hline Tablet, iPad EBC11 & No & Yes & & & & & & & \\
\hline Monthly income EBC12 & No & Yes & & & & & & & \\
\hline \multirow[t]{2}{*}{ EBC Belongings scale } & Continuous & $>4$ & & & & & & & $\begin{array}{l}\text { All characteristics are added up } \\
\text { through variable addition } \\
\text { approach [88], following the } \\
\text { absence-presence EBC pattern. } \\
\text { All EBC characteristics are added, } \\
\text { and a cutting edge is placed in } \\
\text { the middle }\end{array}$ \\
\hline & Low-low & low & Intermediate & High & & & & & $\begin{array}{l}\text { All EBC characteristics are added } \\
\text { and classified in terciles }\end{array}$ \\
\hline
\end{tabular}

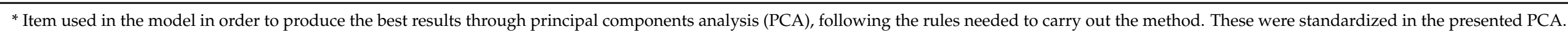

Table A2. Possible variables and categorizations for the health variables. Directionality: 0 is favorable/lack of illness.

\begin{tabular}{|c|c|c|c|c|c|}
\hline Instruction & 0 & 1 & 2 & 3 & Comment \\
\hline Is my health good? & No & Yes & & & ${ }^{*}$ Reverse variable \\
\hline Body Mass Index & $\begin{array}{c}\text { Continuous } \\
\text { Normal or low }<24.94 \\
\text { low }<=18.42\end{array}$ & $\begin{array}{c}\text { Overweight }=>24.96 \&<30 \\
\text { Normal }>18.42 \&<=24.94\end{array}$ & $\begin{array}{c}\text { Obesity }=>30 \\
\text { Overweight }>24.94 \&<30\end{array}$ & Obesity $>=30$ & ${ }^{*}$ Weight $/$ height $(\mathrm{m})^{2}$ \\
\hline Diagnosed as overweight or with obesity? & No & Yes & & & \\
\hline Diagnosed with cancer? & No & Yes & & & \\
\hline Diagnosed with coronary (ischemic) disease? & No & Yes & & & \\
\hline
\end{tabular}


Table A2. Cont.

\begin{tabular}{|c|c|c|c|c|c|}
\hline Instruction & 0 & 1 & 2 & 3 & Comment \\
\hline Diagnosed with cerebrovascular disease? & No & Yes & & & \\
\hline Diagnosed with diabetes? & No & Yes & & & \\
\hline \multirow{2}{*}{ Diagnosed with arterial hypertension? } & No & Yes & & & $\begin{array}{l}\text { Used to build the hypertension vector: hypertension } \\
\text { and high pressure. }\end{array}$ \\
\hline & Not matched & Matched & & & $\begin{array}{l}\text { * The participant was matched in the vector: } \\
\text { hypertension and high pressure }\end{array}$ \\
\hline \multirow[b]{2}{*}{$\begin{array}{l}\text { Have you ever been diagnosed with high } \\
\text { blood pressure? }\end{array}$} & No & Yes & Doesn't know & & \multirow[b]{2}{*}{$\begin{array}{l}\text { People choosing the "doesn't know" option are } \\
\text { assumed as missing data. Used to build the } \\
\text { hypertension vector: hypertension and } \\
\text { high pressure. }\end{array}$} \\
\hline & No & Yes & & & \\
\hline \multirow[b]{2}{*}{ Have you been diagnosed with dyslipidemia? } & No & Yes & & & \multirow[b]{2}{*}{$\begin{array}{l}\text { * The participant was matched in the vector: } \\
\text { HDL-LDL cholesterol, triglycerides }\end{array}$} \\
\hline & Not matched & Matched & & & \\
\hline \multirow[b]{2}{*}{$\begin{array}{l}\text { Have you ever been diagnosed with } \\
\text { high cholesterol? }\end{array}$} & No & Yes & Doesn't know & & \multirow[b]{2}{*}{$\begin{array}{l}\text { People choosing the "doesn't know" option are } \\
\text { assumed as missing data. Used to build the } \\
\text { dyslipidemia vector: HDL-LDL } \\
\text { cholesterol, triglycerides. }\end{array}$} \\
\hline & No & Yes & & & \\
\hline \multirow[b]{2}{*}{$\begin{array}{l}\text { Have you ever been diagnosed with high } \\
\text { triglycerides? }\end{array}$} & No & Yes & Doesn't know & & \multirow[b]{2}{*}{$\begin{array}{l}\text { People choosing the "doesn't know" option are } \\
\text { assumed as missing data. Used to build the } \\
\text { dyslipidemia vector: HDL-LDL } \\
\text { cholesterol, triglycerides. }\end{array}$} \\
\hline & No & Yes & & & \\
\hline \multirow[b]{2}{*}{$\begin{array}{l}\text { Have you ever been diagnosed with low HDL } \\
\text { Cholesterol (good cholesterol)? }\end{array}$} & No & Yes & Doesn't know & & \multirow[b]{2}{*}{$\begin{array}{l}\text { People choosing the "doesn't know" option are } \\
\text { assumed as missing data. Used to build the } \\
\text { dyslipidemia vector: HDL-LDL } \\
\text { cholesterol, triglycerides. }\end{array}$} \\
\hline & No & Yes & & & \\
\hline \multirow[b]{2}{*}{$\begin{array}{l}\text { Have you ever been diagnosed with high LDL } \\
\text { Cholesterol (bad cholesterol)? }\end{array}$} & No & Yes & Doesn't know & & \multirow[b]{2}{*}{$\begin{array}{l}\text { People choosing the "doesn't know" option are } \\
\text { assumed as missing data. Used to build the } \\
\text { dyslipidemia vector: HDL-LDL } \\
\text { cholesterol, triglycerides. }\end{array}$} \\
\hline & No & Yes & & & \\
\hline \multirow{2}{*}{$\begin{array}{l}\text { Have you ever been diagnosed with low } \\
\text { blood pressure? }\end{array}$} & No & Yes & Doesn't know & & \multirow[b]{2}{*}{$\begin{array}{l}\text { People choosing the "doesn't know" option are } \\
\text { assumed as missing data. }\end{array}$} \\
\hline & No & Yes & & & \\
\hline
\end{tabular}


Table A2. Cont.

\begin{tabular}{|c|c|c|c|c|c|}
\hline Instruction & 0 & 1 & 2 & 3 & Comment \\
\hline $\begin{array}{l}\text { Have you ever been diagnosed with } \\
\text { cardiovascular disease? }\end{array}$ & No & Yes & & & \\
\hline $\begin{array}{l}\text { Have you ever been diagnosed with a } \\
\text { mental/psychological disorder? }\end{array}$ & No & Yes & & & * \\
\hline \multirow{2}{*}{$\begin{array}{l}\text { On a scale from } 0 \text { to } 10 \text {, how stressed are } \\
\text { you feeling? }\end{array}$} & Continuous & & & & $\begin{array}{l}{ }^{*} \text { Likert scale assumed as continuous } 0 \text { not stressed } \\
\text { at all-10 very stressed }\end{array}$ \\
\hline & Not stressed at all & Average stress & Very stressed & & Likert $0-10$ categorized in terciles. \\
\hline \multirow{2}{*}{ In general, how tired/fatigued do you feel? } & Continuous & & & & $\begin{array}{l}{ }^{*} \text { Likert scale assumed as continuous } 0 \text { not fatigued } \\
\text { at all-10 very fatigued }\end{array}$ \\
\hline & Not fatigued at all & Average fatigue & Very fatigued & & Likert $0-10$ categorized in terciles. \\
\hline
\end{tabular}

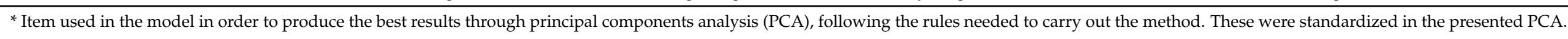

Table A3. Possible variables and categorizations for lifestyle. Directionality: 0 worst lifestyle conditions/unfavorable.

\begin{tabular}{|c|c|c|c|c|}
\hline Instruction & 0 & 1 & 2 & Comment \\
\hline Do you have a sedentary life? & No & Yes & & * Reverse variable \\
\hline Do you exercise 3 times per week? & No & Yes & & * \\
\hline Do you exercise at least 30 min every time? & No & Yes & & * \\
\hline Do you take any medicines? & No & Yes & & Reverse variable \\
\hline Do you smoke? & $\begin{array}{l}\text { No } \\
\text { No or former smoker }\end{array}$ & $\begin{array}{l}\text { Yes } \\
\text { Yes }\end{array}$ & Former smoker & $\begin{array}{l}\text { Former smoker: used to smoke, but not anymore. } \\
{ }^{*} \text { Reverse variable }\end{array}$ \\
\hline Do you drink alcohol? & $\begin{array}{l}\text { No } \\
\text { No or former drinker }\end{array}$ & $\begin{array}{l}\text { Yes } \\
\text { Yes }\end{array}$ & Former drinker & $\begin{array}{l}\text { Former drinker: used to drink, but not anymore. } \\
\text { * Reverse variable }\end{array}$ \\
\hline Do you use any drugs? & Not matched & Matched & & The participant was matched in the vector: marihuana, cocaine, other drugs \\
\hline How many hours do you sleep? & Continuous & $>9$ & $7-9 \mathrm{~h}$ & $\begin{array}{l}\text { Calculation of the total number of hours slept (day and night) } \\
\text { Sleeping less than } 7 \mathrm{~h} \text { per night can lead to adverse health conditions; between } 7 \text { and } \\
9 \mathrm{~h} \text { could be considered a normal range for young adults, while more than } 9 \mathrm{~h} \text { could } \\
\text { be enough for young adults and for people recovering from sleep debt or suffering } \\
\text { from illnesses [66]. }\end{array}$ \\
\hline On a scale from 0 to 10 , how good is your diet? & $\begin{array}{l}\text { Continuous } \\
\text { Bad }\end{array}$ & Average & Good & $\begin{array}{l}\text { Likert scale assumed as continuous } 0 \text { bad diet- } 10 \text { good diet } \\
\text { Likert } 0-10 \text { categorized in terciles. }\end{array}$ \\
\hline Do you use a bike in your city? & No & Yes & & \\
\hline
\end{tabular}

${ }^{*}$ Item used in the model in order to produce the best results through principal components analysis (PCA), following the rules needed to carry out the method. These were standardized in the presented PCA. 


\section{References}

1. Gopalakrishnan, S. A public health perspective of road traffic accidents. J. Fam. Med. Prim. Care 2012, 1, 144-150. [CrossRef] [PubMed]

2. Shrivastava, S.R.; Shrivastava, P.S.; Ramasamy, J. Scope of public health measures in ensuring road safety. J. Inj. Violence Res. 2014, 6, 95-96. [CrossRef] [PubMed]

3. WHO. Global Status Report on Road Safety 2018; World Health Organization: Geneva, Switzerland, 2018.

4. Hyder, A.A.; Paichadze, N.; Toroyan, T.; Peden, M.M. Monitoring the Decade of Action for Global Road Safety 2011-2020: An update. Glob. Public Health 2017, 12, 1492-1505. [CrossRef] [PubMed]

5. Wang, T.; Wang, Y.; Xu, T.; Li, L.; Huo, M.; Li, X.; He, Y.; Lin, Q.; Mei, B.; Zhou, X.; et al. Epidemiological and clinical characteristics of 3327 cases of traffic trauma deaths in Beijing from 2008 to 2017: A retrospective analysis. Medicine 2020, 99, e18567. [CrossRef]

6. Chen, S.; Kuhn, M.; Prettner, K.; Bloom, D.E. The global macroeconomic burden of road injuries: Estimates and projections for 166 countries. Lancet Planet. Health 2019, 3, e390-e398. [CrossRef]

7. Sargazi, A.; Sargazi, A.; Nadakkavukaran Jim, P.K.; Danesh, H.; Aval, F.; Kiani, Z.; Lashkarinia, A.; Sepehri, Z. Economic Burden of Road Traffic Accidents; Report from a Single Center from South Eastern Iran. Bull. Emerg. Trauma 2016, 4, 43-47.

8. Montoro, L.; Alonso, F.; Esteban, C.; Toledo, F. Manual de Seguridad Vial: El Factor Humano, 1st ed.; Barcelona-España: Ariel, Israel, $2000 ;$ p. 384.

9. Jafarpour, S.; Rahimi-Movaghar, V. Determinants of risky driving behavior: A narrative review. Med. J. Islamic Repub. Iran 2014, 28,142 .

10. Touahmia, M. Identification of Risk Factors Influencing Road Traffic Accidents. Eng. Technol. Appl. Sci. Res. 2018, 8, $2417-2421$. [CrossRef]

11. Petridou, E.; Moustaki, M. Human factors in the causation of road traffic crashes. Eur. J. Epidemiol. 2000, 16, 819-826. [CrossRef]

12. Mairean, C.; Havarneanu, C.E. The relationship between drivers' illusion of superiority, aggressive driving, and self-reported risky driving behaviors. Transp. Res. Part F Traffic Psychol. Behav. 2018, 55, 167-174. [CrossRef]

13. Cavacuiti, C.; Ala-Leppilampi, K.J.; Mann, R.E.; Govoni, R.; Stoduto, G.; Smart, R.; Locke, J.A. Victims of Road Rage: A Qualitative Study of the Experiences of Motorists and Vulnerable Road Users. Violence Vict. 2013, 28, 1068-1084. [CrossRef] [PubMed]

14. Alonso, F.; Esteban, C.; Montoro, L.; Serge, A. Conceptualization of aggressive driving behaviors through a Perception of aggressive driving scale (PAD). Transp. Res. Part F Psychol. Behav. 2019, 60, 415-426. [CrossRef]

15. Elgar, F.J.; Pförtner, T.-K.; Moor, I.; De Clercq, B.; Stevens, G.W.J.M.; Currie, C. Socioeconomic inequalities in adolescent health 2002-2010: A time-series analysis of 34 countries participating in the Health Behaviour in School-aged Children study. Lancet 2015, 385, 2088-2095. [CrossRef]

16. Braveman, P.A.; Cubbin, C.; Egerter, S.; Chideya, S.; Marchi, K.S.; Metzler, M.; Posner, S. Socioeconomic Status in Health ResearchOne Size Does Not Fit All. JAMA 2005, 294, 2879-2888. [CrossRef]

17. Flaskerud, J.H.; DeLilly, C.R. Social determinants of health status. Issues Ment. Health Nurs. 2012, 33, 494-497. [CrossRef]

18. Islam, M.M. Social Determinants of Health and Related Inequalities: Confusion and Implications. Front. Public Health $2019,7,11$. [CrossRef]

19. Shafiei, S.; Yazdani, S.; Jadidfard, M.-P.; Zafarmand, A.H. Measurement components of socioeconomic status in health-related studies in Iran. BMC Res. Notes 2019, 12, 70. [CrossRef]

20. Gallo, L.C.; de Los Monteros, K.E.; Shivpuri, S. Socioeconomic Status and Health: What is the role of Reserve Capacity? Curr. Dir. Psychol. Sci. 2009, 18, 269-274. [CrossRef]

21. Van den Berghe, W. The Association between Road Safety and Socioeconomic Situation (SES); An International Literature Review; Vias Institute-Knowledge Centre Road Safety: Brussels, Belgium, 2017.

22. Sehat, M.; Naieni, K.H.; Asadi-Lari, M.; Foroushani, A.R.; Malek-Afzali, H. Socioeconomic Status and Incidence of Traffic Accidents in Metropolitan Tehran: A Population-based Study. Int. J. Prev. Med. 2012, 3, 181-190.

23. Atombo, C.; Wu, C.; Tettehfio, E.O.; Agbo, A.A. Personality, socioeconomic status, attitude, intention and risky driving behavior. Cogent Psychol. 2017, 4, 1376424. [CrossRef]

24. Ngueutsa, R.; Kouabenan, D.R. Accident history, risk perception and traffic safe behaviour. Ergonomics 2017, 60, 1273-1282. [CrossRef] [PubMed]

25. Brown, T.G.; Ouimet, M.C.; Eldeb, M.; Tremblay, J.; Vingilis, E.; Nadeau, L.; Pruessner, J.; Bechara, A. The effect of age on the personality and cognitive characteristics of three distinct risky driving offender groups. Pers. Individ. Differ. 2017, 113, 48-56. [CrossRef]

26. Robert, S.A.; Cherepanov, D.; Palta, M.; Dunham, N.C.; Feeny, D.; Fryback, D.G. Socioeconomic status and age variations in health-related quality of life: Results from the national health measurement study. J. Gerontol. Ser. B Psychol. Sci. Soc. Sci. 2009, 64, 378-389. [CrossRef] [PubMed]

27. Straatmann, V.S.; Lai, E.; Lange, T.; Campbell, M.C.; Wickham, S.; Andersen, A.-M.N.; Strandberg-Larsen, K.; Taylor-Robinson, D. How do early-life factors explain social inequalities in adolescent mental health? Findings from the UK Millennium Cohort Study. J. Epidemiol. Community Health 2019, 73, 1049. [CrossRef] [PubMed] 
28. Noh, J.-W.; Jo, M.; Huh, T.; Cheon, J.; Kwon, Y.D. Gender differences and socioeconomic status in relation to overweight among older Korean people. PLoS ONE 2014, 9, e97990. [CrossRef]

29. Galobardes, B.; Shaw, M.; Lawlor, D.A.; Lynch, J.W.; Smith, G.D. Indicators of socioeconomic position (part 1). J. Epidemiol. Community Health 2006, 60, 7-12. [CrossRef]

30. Saydah, S.H.; Imperatore, G.; Beckles, G.L. Socioeconomic status and mortality: Contribution of health care access and psychological distress among U.S. adults with diagnosed diabetes. Diabetes Care 2013, 36, 49-55. [CrossRef]

31. Back, J.H.; Lee, Y. Gender differences in the association between socioeconomic status (SES) and depressive symptoms in older adults. Arch. Gerontol. Geriatr. 2011, 52, e140-e144. [CrossRef]

32. Jacquet, E.; Robert, S.; Chauvin, P.; Menvielle, G.; Melchior, M.; Ibanez, G. Social inequalities in health and mental health in France. The results of a 2010 population-based survey in Paris Metropolitan Area. PLoS ONE 2018, 13, e0203676. [CrossRef]

33. Marmot, M.G.; Kogevinas, M.; Elston, M.A. Social/economic status and disease. Annu. Rev. Public Health 1987, 8, 111-135. [CrossRef]

34. Adler, N.E.; Ostrove, J.M. Socioeconomic status and health: What we know and what we don't. Ann. N. Y. Acad. Sci. 1999, 896, 3-15. [CrossRef] [PubMed]

35. Winkleby, M.A.; Jatulis, D.E.; Frank, E.; Fortmann, S.P. Socioeconomic status and health: How education, income, and occupation contribute to risk factors for cardiovascular disease. Am. J. Public Health 1992, 82, 816-820. [CrossRef] [PubMed]

36. Khalatbari-Soltani, S.; Cumming, R.G.; Delpierre, C.; Kelly-Irving, M. Importance of collecting data on socioeconomic determinants from the early stage of the COVID-19 outbreak onwards. J. Epidemiol. Community Health 2020. [CrossRef] [PubMed]

37. Fujishiro, K.; Xu, J.; Gong, F. What does "occupation" represent as an indicator of socioeconomic status?: Exploring occupational prestige and health. Soc. Sci. Med. 2010, 71, 2100-2107. [CrossRef] [PubMed]

38. Polinder, S.; Haagsma, J.; Bos, N.; Panneman, M.; Wolt, K.K.; Brugmans, M.; Weijermars, W.; van Beeck, E. Burden of road traffic injuries: Disability-adjusted life years in relation to hospitalization and the maximum abbreviated injury scale. Accid. Anal. Prev. 2015, 80, 193-200. [CrossRef]

39. Taylor, A.H.; Dorn, L. Stress, fatigue, health, and risk of road traffic accidents among professional drivers: The contribution of physical inactivity. Annu Rev. Public Health 2006, 27, 371-391. [CrossRef]

40. Ding, D.; Gebel, K.; Phongsavan, P.; Bauman, A.E.; Merom, D. Driving: A road to unhealthy lifestyles and poor health outcomes. PLoS ONE 2014, 9, e94602. [CrossRef]

41. Abdoli, N.; Farnia, V.; Delavar, A.; Esmaeili, A.; Dortaj, F.; Farrokhi, N.; Karami, M.; Shakeri, J.; Holsboer-Trachsler, E.; Brand, S. Poor mental health status and aggression are associated with poor driving behavior among male traffic offenders. Neuropsychiatr. Dis. Treat. 2015, 11, 2071-2078. [CrossRef]

42. Zhu, S.; Layde, P.M.; Guse, C.E.; Laud, P.W.; Pintar, F.; Nirula, R.; Hargarten, S. Obesity and risk for death due to motor vehicle crashes. Am. J. Public Health 2006, 96, 734-739. [CrossRef]

43. Homaie Rad, E.; Khodadady-Hasankiadeh, N.; Kouchakinejad-Eramsadati, L.; Javadi, F.; Haghdoost, Z.; Hosseinpour, M.; Tavakoli, M.; Davoudi-Kiakalayeh, A.; Mohtasham-Amiri, Z.; Yousefzadeh-Chabok, S. The relationship between weight indices and injuries and mortalities caused by the motor vehicle accidents: A systematic review and meta-analysis. J. Inj. Violence Res. 2020, 12, 85-101. [CrossRef] [PubMed]

44. Wang, J.; Geng, L. Effects of Socioeconomic Status on Physical and Psychological Health: Lifestyle as a Mediator. Int. J. Environ. Res. Public Health 2019, 16, 281. [CrossRef] [PubMed]

45. Williams, J.L.; Rheingold, A.A.; Knowlton, A.W.; Saunders, B.E.; Kilpatrick, D.G. Associations between motor vehicle crashes and mental health problems: Data from the National Survey of Adolescents-Replication. J. Trauma. Stress 2015, 28, 41-48. [CrossRef] [PubMed]

46. Shadloo, B.; Motevalian, A.; Rahimi-Movaghar, V.; Amin-Esmaeili, M.; Sharifi, V.; Hajebi, A.; Radgoodarzi, R.; Hefazi, M.; Rahimi-Movaghar, A. Psychiatric Disorders Are Associated with an Increased Risk of Injuries: Data from the Iranian Mental Health Survey (IranMHS). Iran. J. Public Health 2016, 45, 623-635. [PubMed]

47. Alarcón, J.D.; Saladich, I.G.; Cuellar, L.V.; Gallardo, A.M.R.; Arce, C.M.; Cosp, X.B. Mortality caused by traffic accidents in colombia. comparison with other countries. Safety 2020, 2011, 2.

48. Oviedo-Trespalacios, O.; Scott-Parker, B. The sex disparity in risky driving: A survey of Colombian young drivers. Traffic Inj. Prev. 2018, 19, 9-17. [CrossRef]

49. DANE. Censo Nacional de Población y Vivienda 2018. Available online: https://sitios.dane.gov.co/cnpv/\#!/ (accessed on 15 March 2020).

50. Brysbaert, M. How Many Participants Do We Have to Include in Properly Powered Experiments? A Tutorial of Power Analysis with Reference Tables. J. Cogn. 2019, 2, 16. [CrossRef]

51. Trafimow, D.; Myüz, H.A. The sampling precision of research in five major areas of psychology. Behav. Res. Methods 2019, 51, 2039-2058. [CrossRef]

52. Riley, R.D.; Snell, K.I.; Ensor, J.; Burke, D.L.; Harrell, F.E., Jr.; Moons, K.G.; Collins, G.S. Minimum sample size for developing a multivariable prediction model: PART II-binary and time-to-event outcomes. Stat. Med. 2019, 38, 1276-1296. [CrossRef]

53. Kadam, P.; Bhalerao, S. Sample size calculation. Int. J. Ayurveda Res. 2010, 1, 55-57. [CrossRef]

54. Piovesana, A.; Senior, G. How small is big: Sample size and skewness. Assessment 2018, 25, 793-800. [CrossRef] 
55. Congreso República Colombia. Ley Estatutaria 1885 de 2018 por la Cual se Modifica la Ley 1622 de 2013 y se Dictan Otras Disposiciones; Colombia, C.d.1.R.d., Ed.; Corte Constitucional de Colombia: Bogotá, Colombia, 2018; p. 20.

56. DANE. Panorama Sociodemográfico de la Juventud en Colombia ¿Quiénes son, Qué Hacen y Cómo se Sienten en el Contexto Actual? Available online: https://www.dane.gov.co/files/investigaciones/genero/informes/informe-panoramasociodemografico-juventud-en-colombia.pdf (accessed on 29 September 2020).

57. Van Selm, M.; Jankowski, N.W. Conducting online surveys. Qual. Quant. 2006, 40, 435-456. [CrossRef]

58. Regmi, P.R.; Waithaka, E.; Paudyal, A.; Simkhada, P.; Van Teijlingen, E. Guide to the design and application of online questionnaire surveys. Nepal J. Epidemiol. 2016, 6, 640. [CrossRef] [PubMed]

59. Jafari, M.; Ansari-Pour, N. Why, When and How to Adjust Your P Values? Cell J. 2019, 20, 604-607. [CrossRef] [PubMed]

60. A Language and Environment for Statistical Computing. Available online: https://www.yumpu.com/en/document/read/6853 895/r-a-language-and-environment-for-statistical-computing (accessed on 29 September 2020).

61. Chao, Y.-S.; Wu, C.-J. Principal component-based weighted indices and a framework to evaluate indices: Results from the Medical Expenditure Panel Survey 1996 to 2011. PLoS ONE 2017, 12, e0183997. [CrossRef] [PubMed]

62. Howe, L.D.; Hargreaves, J.R.; Huttly, S.R.A. Issues in the construction of wealth indices for the measurement of socio-economic position in low-income countries. Emerg. Themes Epidemiol. 2008, 5, 3. [CrossRef]

63. Congreso República Colombia. Ley 142 de 1994. In Diario Oficial 41.433; Colombia, C.d.l.R.d., Ed.; Corte Constitucional de Colombia: Bogotá, Colombia, 1994.

64. DANE. Encuesta Nacional de Presupuestos de los Hogares (ENPH) 2016-2017. Boletín Técnico. Departamento Administrativo Nacional de Estadística (DANE). Available online: https:/ / www.dane.gov.co/files/investigaciones/boletines/enph/boletinenph-2017.pdf (accessed on 3 July 2020).

65. Mudrazija, S.; Angel, J.L.; Cipin, I.; Smolic, S. Living Alone in the United States and Europe: The Impact of Public Support on the Independence of Older Adults. Res. Aging 2020, 42, 150-162. [CrossRef]

66. Watson, N.F.; Badr, M.S.; Belenky, G.; Bliwise, D.L.; Buxton, O.M.; Buysse, D.; Dinges, D.F.; Gangwisch, J.; Grandner, M.A.; Kushida, C.; et al. Recommended Amount of Sleep for a Healthy Adult: A Joint Consensus Statement of the American Academy of Sleep Medicine and Sleep Research Society. Sleep 2015, 38, 843-844. [CrossRef]

67. Williams, A.F.; Shabanova, V.I. Responsibility of drivers, by age and gender, for motor-vehicle crash deaths. J. Saf. Res. 2003, 34, 527-531. [CrossRef]

68. COLPSIC, C.C.d.P. Deontología y Bioética del Ejercicio de la Psicología en Colombia; Editorial El Manual Moderno Colombia: Bogotá, Colombia, 2016.

69. Amerson, R.M.; Strang, C.W. Addressing the Challenges of Conducting Research in Developing Countries. J. Nurs. Scholarsh. Off. Publ. Sigma Theta Tau Int. Honor Soc. Nurs. 2015, 47, 584-591. [CrossRef]

70. Lonczak, H.S.; Neighbors, C.; Donovan, D.M. Predicting risky and angry driving as a function of gender. Accid. Anal. Prev. 2007, 39, 536-545. [CrossRef]

71. Özkan, T.; Lajunen, T. What causes the differences in driving between young men and women? The effects of gender roles and sex on young drivers' driving behaviour and self-assessment of skills. Transp. Res. Part F Traffic Psychol. Behav. 2006, 9, 269-277. [CrossRef]

72. Roshanfekr, P.; Khodaie-Ardakani, M.-R.; Malek Afzali Ardakani, H.; Sajjadi, H. Prevalence and Socio-Economic Determinants of Disabilities Caused by Road Traffic Accidents in Iran; A National Survey. Bull. Emerg. Trauma 2019, 7, 60-66. [CrossRef] [PubMed]

73. Landale, N.S.; Oropesa, R.S.; Bradatan, C. Hispanic families in the United States: Family Structure and Process in an Era of Family Change. In Hispanics and the Future of America; National Academies Press: Washington, DC, USA, 2006 ; Volume 5.

74. Hurtado, D.; Kawachi, I.; Sudarsky, J. Social capital and self-rated health in Colombia: The good, the bad and the ugly. Soc. Sci. Med. 2011, 72, 584-590. [CrossRef] [PubMed]

75. Woodcock, J.; Aldred, R. Cars, corporations, and commodities: Consequences for the social determinants of health. Emerg. Themes Epidemiol. 2008, 5, 4. [CrossRef] [PubMed]

76. Kim, J.-K.; Ulfarsson, G.F.; Shankar, V.N.; Kim, S. Age and pedestrian injury severity in motor-vehicle crashes: A heteroskedastic logit analysis. Accid. Anal. Prev. 2008, 40, 1695-1702. [CrossRef]

77. Villaveces, A.; Nieto, L.A.; Ortega, D.; Rios, J.F.; Medina, J.J.; Gutierrez, M.I.; Rodriguez, D. Pedestrians' perceptions of walkability and safety in relation to the built environment in Cali, Colombia, 2009-2010. Inj. Prev. J. Int. Soc. Child Adolesc. Inj. Prev. 2012, 18, 291-297. [CrossRef]

78. Greening, L.; Stoppelbein, L. Young drivers' health attitudes and intentions to drink and drive. J. Adolesc. Health 2000, $27,94-101$. [CrossRef]

79. Evans, R. Cycling and health. Doctors should cycle and recommend it to their patients. BMJ (Clin. Res. Ed.) 2000, $321,386$.

80. Shariat, A.; Ansari, N.N.; Cleland, J.A.; Hakakzadeh, A.; Kordi, R.; Kargarfard, M. Therapeutic Effects of Cycling on Disability, Mobility, and Quality of Life in Patients Post Stroke. Iran. J. Public Health 2019, 48, 355-356. [CrossRef]

81. Leyland, L.-A.; Spencer, B.; Beale, N.; Jones, T.; van Reekum, C.M. The effect of cycling on cognitive function and well-being in older adults. PLoS ONE 2019, 14, e211779. [CrossRef]

82. Mackay, A.; Mackay, D.F.; Celis-Morales, C.A.; Lyall, D.M.; Gray, S.R.; Sattar, N.; Gill, J.M.R.; Pell, J.P.; Anderson, J.J. The association between driving time and unhealthy lifestyles: A cross-sectional, general population study of 386493 UK Biobank participants. J. Public Health 2019, 41, 527-534. [CrossRef] [PubMed] 
83. Brandt, C.J.; Clemensen, J.; Nielsen, J.B.; Søndergaard, J. Drivers for successful long-term lifestyle change, the role of e-health: A qualitative interview study. BMJ Open 2018, 8, e017466. [CrossRef] [PubMed]

84. Mechakra-Tahiri, S.D.; Freeman, E.E.; Haddad, S.; Samson, E.; Zunzunegui, M.V. The gender gap in mobility: A global crosssectional study. BMC Public Health 2012, 12, 598. [CrossRef] [PubMed]

85. Arora, S.K.; Shah, D.; Chaturvedi, S.; Gupta, P. Defining and Measuring Vulnerability in Young People. Indian J. Community Med. Off. Publ. Indian Assoc. Prev. Soc. Med. 2015, 40, 193-197. [CrossRef]

86. Christensen, H.; Reynolds, C.F.R.; Cuijpers, P. Protecting youth mental health, protecting our future. World Psychiatry 2017, 16, 327-328. [CrossRef]

87. Ross, L.A.; Schmidt, E.L.; Ball, K. Interventions to maintain mobility: What works? Accid. Anal. Prev. 2013, 61, 167-196. [CrossRef]

88. Reckien, D. What is in an index? Construction method, data metric, and weighting scheme determine the outcome of composite social vulnerability indices in New York City. Reg. Environ. Chang. 2018, 18, 1439-1451. [CrossRef]

89. Buitrago-Lopez, A.; Van den Hooven, E.H.; Rueda-Clausen, C.F.; Serrano, N.; Ruiz, A.J.; Pereira, M.A.; Mueller, N.T. Socioeconomic status is positively associated with measures of adiposity and insulin resistance, but inversely associated with dyslipidaemia in Colombian children. J. Epidemiol Community Health 2015, 69, 580-587. [CrossRef]

90. Villamor, E.; Mora-Plazas, M.; Forero, Y.; Lopez-Arana, S.; Baylin, A. Vitamin B-12 status is associated with socioeconomic level and adherence to an animal food dietary pattern in Colombian school children. J. Nutr. 2008, 138, 1391-1398. [CrossRef] 